\title{
An Additive Manufacturing Approach to Bioreactor Design for Mesenchymal Stem Cell Culture
}

\author{
Authors \\ Akinlolu Oyekunle Oluseun Odeleye ${ }^{1,2}$ \\ Timothee Baudequin ${ }^{1}$ \\ Chih-Yao Chui ${ }^{1}$ \\ Zhanfeng Cui ${ }^{1}$ \\ Hua $\mathrm{Ye}^{* 1}$
}

\section{Author Affiliations}

${ }^{1}$ Institute of Biomedical Engineering, Department of Engineering Science, University of Oxford, OX3 7DQ, UK

${ }^{2}$ Current affiliation: Adaptimmune Limited, 60 Jubilee Avenue, Milton Park, Abingdon, OX14 4RX, UK

\section{*Corresponding Author}

Name: Professor Hua Ye

Address: Institute of Biomedical Engineering, Department of Engineering Science,

University of Oxford, Old Road Campus Research Building, Roosevelt Drive, OX3 7DQ, UK Email: Hua.Ye@eng.ox.ac.uk

Tel: + $44(0) 1865617689$ 


\section{Abstract}

Bioreactor design is a challenging endeavour that aims to provide the most ideal environment in which cells can grow and biological reactions can occur. The emergence of regenerative medicine and stem cell therapies has led to the need for more diverse environmental requirements in the bioreactor design space.

The study presented uses an additive manufacturing approach for the initial design phase of a packed/fluidized bed bioreactor for mesenchymal stem cell expansion. Combining 3D-printing with CFD for precision control over the bioreactor flow dynamics. Novel flow distributors were developed to engender swirling particle fluidization. The design was simulated and optimised using CFD, demonstrating an increase from $0.01 \mathrm{~m} / \mathrm{s}$ to $0.02 \mathrm{~m} / \mathrm{s}$ in the radial velocity of $3.0 \mathrm{~mm}$ macrocarriers $\left(1080 \mathrm{~kg} / \mathrm{m}^{3}\right)$ at the minimum fluidization velocity. An autoclavable prototype was constructed to illustrate proof-of-concept in the use of swirling flow distribution to enhance cell attachment efficiency (compared to static culture system). Commercial Cytodex 1 carriers were tested: an improvement in attachment efficiency after 24 hours from $50 \%$ to $95 \%$ was induced by the swirling flow distributor, with subsequent expansion of 2.4-fold after 6 days of culture.

The computational design, modelling and 3D-printing of complex geometric architecture that control the flow dynamics within a bioreactor, provides a novel approach to bioprocess unit operation development for manufacturing novel ATMPs.

Keywords: Additive Manufacturing, Computational Fluid Dynamics, Bioreactor Design, Swirling Fluidization, Mesenchymal Stem Cells.

\section{Introduction}

The application of regenerative medicines, including cell-based therapies such as human mesenchymal stem cells (hMSCs) and tissue replacement or restoration of tissue function, is predicted to be the next revolution within healthcare [1]. The capacity for self-renewal and ability to differentiate into multiple cell types that hMSCs possess, signifies their great therapeutic potential in cell therapy [2]. Mesenchymal stem cells are widely used in clinical trials for cell therapy due to their immunoregulatory, self-renewal and differentiation properties [3], [4]. Although the clinical potential of stem cell therapy is evident, to date, the ability to produce the necessary quantities of these adherent cells is limited. Establishing reliable and robust methods of stem cell expansion are necessary for MSCs to fulfil their therapeutic potential in the wider population and to bring these novel therapies to the patient. However, the culture of stem cells is governed by factors both biological and engineering, that are not yet fully understood. The process of using the cells themselves as the therapeutic agent, as opposed to recombinant protein biopharmaceuticals, means that the design of such systems requires additional care 
and consideration than their protein-producing counterparts. It is critical for the cells to be functional (thus cells should be expanded with fewer than 20 population doublings), as well as grown within a well-defined environment in which physiochemical, nutritional and fluid mechanical requirements are maintained and controlled [5].

The increase of the required lot sizes of human multipotent and pluripotent stem cells ( $10^{9}$ to $10^{12}$ cells) have resulted in the emergence of a number of different strategies to culture adherent stem cells for cell therapy [6], [7]. These include stirred, multi-layered, hollow fibre, roller bottle and packed bed systems. The most widely used nowadays are still tissue culture flasks which provide a flat $2 \mathrm{D}$ culture surface for cell adherence. This approach to expand anchorage dependent cells is well established, though labour intensive and time consuming. With the need for an increased production capacity, there has been a shift from the use of 2D T flasks to 3D microcarrier-based bioreactor platforms. Small scale (100 $\mathrm{mL}$ ) magnetically stirred spinner flasks are now being expanded to 5-L-scale stirred bioreactors [8]. These culture methods typically present a 5 to 6-fold increase in cell number [7], [8]. Other suspension stirred systems include the Celligen ${ }^{\circledR}$ BioBLU (Eppendorf, Hauppauge, NY, USA), DASGIP Parallel Bioreactor system, PADReactor (Pall Life Sciences), UniVessel ${ }^{\circledR}$ SU (Sartorius, Göttingen, Germany) and MiniBio (Applikon Biotechnology, Delft, Netherlands). These systems are closed and facilitate monitoring of $\mathrm{pH}$, dissolved oxygen and metabolites. In stirred bioreactors, the hydrodynamic stresses induced by the impeller should be carefully considered. Although agitation is required for cell culture homogeneity, low agitation rates can result in cell and microcarrier aggregation. Whilst if the agitation rate is too high, the levels of shear stresses induced can be detrimental to the cells. Fluid mechanical forces can also influence stem cell differentiation fate [9]. Multi-layered systems such as the Nunc Cell Factory, Thermo Fisher Scientific, MA, USA; Corning Cell-STACK, Corning, NY, USA, are simple to operate due to their similarity to $2 \mathrm{D}$ culture flasks. However, there are difficulties in monitoring and controlling the system, also, a lack of uniformity regarding cell adherence may result in cell heterogeneity [10]. Pall have attempted to address this with the release of a single-use multi-layered system (Integrity Xpansion, Pall, NY, USA) with integrated temperature, $\mathrm{pH}$ and dissolved oxygen control. Packed bed systems incorporate the use of beads, fibres, hollow fibres and porous structures. Their advantages include high cell densities, real-time control and low shear forces upon the cells. However, achieving uniform distribution during seeding and efficient cell detachment during harvest are challenges that need addressing. Furthermore, the maintenance of a homogenous environment of oxygen and nutrient is another challenge. Accordingly, there is great scope to improve stem cell therapy production in relation to cell attachment, detachment, monitoring/control and regarding the cell microenvironment.

The adherent nature of MSCs defines the methods employed for expansion with static (packed beds, stacked plates) or dynamically mixed (stirred, shaken, fluidized) systems available for adaptation to stem cell proliferation. Although fluidized beds are widely used in the chemical process industries [11]- 
[13], their implementation in stem cell culture is limited [14]. However, with careful design, their favourable heat and mass transfer characteristics can enhance the uniformity of the cell culture environment; compared to systems agitated by an external solid component (e.g. impeller).

The aim of this study was to design a novel bioreactor for the expansion of mesenchymal stem cells for autologous cell therapy. The considerations presented illustrate the challenges of bioreactor design for adherent stem cell expansion. A variety of articles have investigated the fluid dynamics within bioreactors and a number have combined hydrodynamics data with biological studies to characterise current technologies and augment bioreactor design [15]-[24]. The article presented proposes a new approach to bioreactor design and manufacture; utilising additive manufacturing to manipulate multiphase flow and employing computational fluid dynamics to augment and validate the design. The bioreactor will be a packed bed system with intermittent particle fluidization, capable of utilising bespoke macrocarrier technology and commercial microcarriers. The preliminary design stage incorporated computational fluid dynamics with experimental validation (utilising calcium alginate beads in a Perspex model prototype) to ensure the optimum flow distributor design is attained efficiently. An autoclavable prototype is subsequently developed as a proof-of-concept to assess MSC inoculation and proliferation within the bioreactor using commercial Cytodex 1 microcarriers.

\section{Materials \& Methods}

\subsection{Design Considerations}

Typical mesenchymal stem cell therapy dose administered to patients suffering from multiple sclerosis ranged from 1.1 to $2 \times 10^{6}$ cells per kg bodyweight [25]. A separate study indicated a $>70$ point reduction in the Crohn's disease activity index (CDAI), for one third of patients administered with two doses of $2 \times 10^{6}$ cells $/ \mathrm{kg}$ bodyweight of autologous MSCs [26]. For this design study, a mesenchymal stem cell therapy dose of $2 \times 10^{6}$ cells per kg bodyweight was therefore assumed. To allow for multiple doses of cell therapy, a maximum target cell number at harvest chosen for the autologous stem cell bioreactor was $1 \times 10^{9}$ cells. Table 1 identifies key geometric parameters of the bioreactor that would enable the target dose to be achieved.

Table 1: Target cell therapy dose and required bioreactor lot size.

\begin{tabular}{|c|c|c|c|}
\hline Key Parameters & Values & Units & Source \\
\hline MSC Dose Range & 1 to $2 \times 10^{6}$ & $\begin{array}{c}\text { cells/kg } \\
\text { bodyweight }\end{array}$ & {$[25],[26]$} \\
\hline $\begin{array}{c}\text { Maximum Target Cell } \\
\text { Number (at harvest) }\end{array}$ & $1 \times 10^{9}$ & cells & N/A \\
\hline
\end{tabular}




\begin{tabular}{|c|c|c|c|}
\hline $\begin{array}{c}\text { Cell Coverage at } \\
\text { Confluence }\end{array}$ & $1 \times 10^{5}$ & cells $/ \mathrm{cm}^{2}$ & $\begin{array}{c}\text { Thermofisher \& GE } \\
\text { Healthcare documentation }\end{array}$ \\
\hline $\begin{array}{l}\text { Required Surface Area } \\
\qquad\left(\mathbf{c m}^{2}\right)\end{array}$ & 10,000 & $\mathrm{~cm}^{2}$ & N/A \\
\hline Packed Bed Voidage & 0.259 & dimensionless & N/A \\
\hline $\begin{array}{c}\text { Minimum Fluidized } \\
\text { Voidage }\end{array}$ & 0.4 & dimensionless & [27] \\
\hline
\end{tabular}

The micro and macrocarrier sizes can be chosen to manipulate the available surface area and achieve the cell dose required. This is indicated with examples of macrocarrier diameters in Table 2, in which the packed/fluidized bed height and particle surface area are presented. Microcarriers exhibit a much higher surface area to volume ratio, resulting in a low H/D ratio. To accommodate the use of different adherent carriers, computational fluid dynamics and additive manufacturing methods were employed to mitigate the design limitations associated with macro and micro-sized particles, by increasing the radial component of particle flux to ensure uniform mixing and cell distribution.

$\underline{\text { Table 2: Harvest Cell Number for Different Bead Sizes }}$

\begin{tabular}{|c|c|c|c|c|}
\hline $\begin{array}{c}\text { Bead Diameter } \\
(\mathbf{m m})\end{array}$ & $\begin{array}{c}\text { Selected Surface } \\
\text { Area }\left(\mathbf{c m}^{\mathbf{2}}\right)\end{array}$ & $\begin{array}{c}\text { Packed Bed } \\
\text { Height }(\mathbf{c m})\end{array}$ & $\begin{array}{c}\text { Minimum } \\
\text { Fluidized Bed } \\
\text { Height }(\mathbf{c m})\end{array}$ & $\begin{array}{c}\text { Maximum } \\
\text { Cell Number }\end{array}$ \\
\hline $\mathbf{3}$ & 10000 & 8.6 & 10.6 & $1.00 \times 10^{9}$ \\
\hline $\mathbf{4}$ & 9000 & 10.3 & 12.7 & $9.00 \times 10^{8}$ \\
\hline $\mathbf{5}$ & 7000 & 10.0 & 12.4 & $7.00 \times 10^{8}$ \\
\hline $\mathbf{6}$ & 6000 & 10.3 & 12.7 & $6.00 \times 10^{8}$ \\
\hline
\end{tabular}

\subsection{Prototype Bioreactor Design \& Set-Up}

The bioreactor is designed to accommodate a surface area for MSC adherence of up to $10,000 \mathrm{~cm}^{2}$, with the capacity to use a variety of different carrier types including: porous, non-porous, micro and macrocarriers. Non-porous macrocarriers occupy the greatest area per unit volume and have the added benefit of easier cell clarification at the cell harvest stage. As such, a vessel with a 2:1 ratio of H/D is designed with dimensions provided in Table 1. A technical drawing of the vessel is shown in Figure 3, illustrating the main components that comprise the vessel.

Figure 1a shows the detailed drawing of the prototype and Figure 1b illustrates an image of the bioreactor. The system comprises of the plenum (fluid inlet zone), bead column and a flow distributor plate. The designed fluidized bed bioreactor was fabricated as an autoclavable prototype, consisting of 
acetal resin flanges (two), a bottom-plate and a head-plate. The two flanges sandwich a 3D printed flow distributor, which are in turn enclosed by two glass cylinders with $0.1 \mathrm{~m}$ ID and $0.01 \mathrm{~m}$ wall thickness (chamfered). The two glass cylinders are $0.04 \mathrm{~m}$ and $0.10 \mathrm{~m}$ in height, which correspond to the plenum and main culture chamber, respectively. Within the plenum is a 3D printed cylinder with a perforated base. The 3D printed cylinder contains $5 \mathrm{~mm}$ glass beads (Sigma Aldrich) packed at a height of $2 \mathrm{~cm}$ (to homogenise the incoming fluid flow). The head-plate and bottom-plate both enclose the vessel. The bioreactor is compression sealed using eight steel rods through the acetal resin components.

The flow distributor and cylinder (within the plenum) was manufactured in-house using a Form 2 3Dprinter using the Dental SG resin (Formlabs, USA, USP Class VI). All components were post-cured according to the manufacturer's protocol. A $0.01-\mathrm{m}$ diameter, $10 \mu \mathrm{m}$ pore polycarbonate etched membrane (Sterlitech, USA) was attached on top of the flow distributor to prevent microcarriers entering the flow distributor flow channels.

Once the bioreactor is assembled, a solution of $1 \%$ Virkon is flushed through the entirety of the vessel and allowed to sit for 30 mins. The vessel is then flushed with reverse osmosis (RO) water three times to wash away any residual Virkon. The bioreactor is then autoclaved on a dry cycle at $134^{\circ} \mathrm{C}$ for 15 mins. The head-plate screws are loosened prior to autoclaving, leaving $2 \mathrm{~mm}$ of space for the vessel to expand when being autoclaved.

The cylindrical vessel has an inner diameter of $0.1 \mathrm{~m}$, a plenum height of $0.04 \mathrm{~m}$, a column height of 0.175 and a total height of $0.247 \mathrm{~m}$. Two thread-to-hose barb adaptors are fitted on the bottom and top of the vessel for the inlet and outlet tubing respectively. An Ismatec pump and Easy Load II pump head are used to input the fluidizing liquid (cell culture media) to fluidized the bed of carriers. The vessel dimensions for the prototype were chosen to facilitate the range of particle sizes proposed, whilst ensuring that the bed height (L) to vessel diameter (D) ratio is within the typical range (L/D = 1 to 2 ) used for packed/fluidized bed systems [28]. Thus, the bead size can be chosen depending on the required surface area and cell dose required.

The flow distributor is a crucial part of any fluidized bed system. The typical role of the distributor is to induce uniformity of flow within the particle bed, and to ensure sufficient mass and nutrient transfer to/from the fluidized particles [29]. As a system for the culturing of adherent cells for cell therapy, there are additional characteristics and objectives that the flow distributor design process must consider. This includes the convection required to distribute cells, nutrients and carriers, along with turbulence and shear stress levels that are amenable to mesenchymal cell culture. The bioreactor itself will operate in an intermittent fluidized state, with the primary aim of fluidization to efficiently mix the macrocarriers and facilitate adherent surface availability during cell culture. Such a process will need to mix the beads in both axial and radial directions and simultaneously mitigate any elutriation of beads of varying size and density. To achieve carrier mixing whilst minimising turbulence, elutriation and shear effects, the 
3D printing capabilities at the University of Oxford combined with CFD were utilised to optimise the design. Two approaches were selected for investigation, a vertically fluidizing distributor and a swirling flow distributor with $45^{\circ}$ angled flow channels.

\subsection{CFD Formulation}

The bioreactor was designed to accommodate a surface area for MSC adherence of up to $10,000 \mathrm{~cm}^{2}$, with the capacity to use a variety of different carrier types including: porous, non-porous, micro and macrocarriers. It is commonly known that both micro- and macro-carriers offer extremely high surface/volume ratio and thus allow for achieving the expected total surface area [30]. The flow distribution within the bioreactor design was optimised through CFD analysis, and an initial Perspex fluidized bed model was designed (with dimensions provided in Table 3) to validate the model. The vessel dimensions were chosen to facilitate a wide range of particle sizes (from $200 \mu \mathrm{m}$ microcarriers, to $0.005 \mathrm{~m}$ macrocarriers), whilst ensuring that the bed height (L) to vessel diameter (D) ratio does not exceed the typical range ( $\mathrm{L} / \mathrm{D}=1$ to 2 ) used for packed/fluidized bed systems [28]. Thus, the bead size can be chosen depending on the required surface area and cell dose required.

\section{Table 3: Geometric Parameters of Prototype}

\begin{tabular}{|l|r|l|}
\hline Vessel Dimensions & Value & Units \\
\hline Column Diameter (D) & 10 & $\mathrm{~cm}$ \\
\hline Column Height (H) & 17.5 & $\mathrm{~cm}$ \\
\hline Cross-Sectional Area (A) & 78.5 & $\mathrm{~cm}^{2}$ \\
\hline $\begin{array}{l}\text { Empty Vessel Volume } \\
(\mathbf{V})\end{array}$ & 1374.4 & $\mathrm{~cm}^{3}$ \\
\hline
\end{tabular}

The multiphase simulation physical properties were set to mimic the experimental conditions within the Perspex model. Calcium alginate beads were selected as the particulate material given its potential use within the final bioreactor. The calcium alginate beads also benefit from ease of visualisation, to accurately measure the particle bed height and determine the minimum fluidization velocity of the beads, in addition to easier handling (microcarriers can adhere to vessel walls in the absence of specific coating [31]). The simulation results were validated using experimental fluidization data obtained with calcium alginate beads. Sodium alginate (Sigma-aldrich, USA) and calcium chloride (Sigma-aldrich, USA) were diluted in demineralized water to prepare $2 \% \mathrm{wt} / \mathrm{v}$ alginate solution and $102 \mathrm{mM}$ crosslinker solution, respectively. Alginate solution was dropped at constant flow rate in the cross-linker solution to form beads $\left(3.0 \mathrm{~mm}\right.$ in diameter, s.d. 0.068 and a density of $1080 \mathrm{~kg} / \mathrm{m}^{3}$ ). Beads were then washed three times with demineralized water before inoculation in the vessel model. The bead bed height was set to $0.1 \mathrm{~m}$. 
The two-phase Eulerian-Eulerian approach was used in the model reported here using ANSYS Fluent. This approach treats the liquid and solid phase mathematically as interpenetrating continuous phases. The Eulerian-Eulerian method includes the conservation of mass and momentum for the solid and liquid phases. Interactions between the phases include momentum exchange mechanisms that involve the lift, drag and added mass force [32]. In this case, the drag force only will be considered. The solid phase can also be treated as a defined sphere using a Eulerian-Lagrangian model, however this method is not ideal for dense multiphase flows (i.e. solid phase $>10 \%$ volume fraction in the fluid) due to the considerable computational resources required [33], [34].

There are numerous models to estimate the drag forces in two phase flow. In the simulation presented, the Gidaspow drag model (a combination of the Wen Yu model and the Ergun equation), enhanced by introducing the kinetic theory of granular flow (KTGF), has been used [35]. This is a widely used correlation for fluidized beds [32], [36], recommended for very dense liquid-solid flows (as seen in Ansys Fluent 16.0 Guidebook). It combines both the Ergun equation and Wen Yu drag model as shown in the equations below (please refer to nomenclature for complete definition of variables).

The Wen Yu model is given by equation 1:

$K_{p l}=\frac{3 \rho_{l} \varepsilon_{l}\left(1-\varepsilon_{l}\right)}{4 d_{p}} C_{D}\left|\overrightarrow{u_{p}}-\overrightarrow{u_{l}}\right| \varepsilon_{l}^{-2.65}$

$C_{D}$ represents the drag factor for a spherical particle and is given by equation 2 :

$C_{D}=\frac{24}{\varepsilon_{l} R e_{p}}\left[1+0.15\left(\varepsilon_{l} R e_{p}\right)^{0.687}\right]$

The Ergun equation is shown in equation 3:

$K_{p l}=150 \frac{\mu_{l}\left(1-\varepsilon_{l}\right) \varepsilon_{p}}{\varepsilon_{l}\left(d_{p} \varphi\right)^{2}}+1.75 \frac{\rho_{l}\left|\overrightarrow{u_{p}}-\overrightarrow{u_{l}}\right|\left(1-\varepsilon_{l}\right)}{d_{p} \varphi}$

Combining the two drag models gives:

$K_{p l}= \begin{cases}K_{p l}(\text { Wen } Y u) & \varepsilon_{l}>0.8 \\ K_{p l}(\text { Ergun }) & \varepsilon_{l} \leq 0.8\end{cases}$

The solid phase properties were defined by the kinetic theory of granular flow presented by Lun et al. (1984). The kinetic theory of granular flow describes the interaction between particles in a fluid and is linked to the kinetic gas theory [38]. Granular temperature can be introduced as a measure of particle velocity fluctuation and is an analogy of the kinetic theory of gases [37].

Further parameters can be calculated using the correlations below [32]:

Solid bulk viscosity - Lun et al. (1984) 
$\lambda_{s}=\frac{4}{5} \varepsilon_{p} \rho_{p} d_{p} g_{0, s s}\left(1-e_{S S}\right)\left(\frac{\Theta_{p}}{\pi}\right)^{1 / 2}$

Frictional viscosity $-[39]$

$\mu_{p, f r i}=\frac{P_{S} \sin (\phi)}{\sqrt[2]{I_{2 D}}}$

Once the CFD model was prepared, a variety of flow distributor designs were tested to assess the radial flow distribution engendered by the novel flow distributor. Flow channels at an angle of $45^{\circ}$, equally space in concentric rings, and parallel to their respective tangent lines on the circular flow distributor disc is presented in this article. The particle velocity induced by the swirling flow distributor was compared to a traditional flow distributor configuration (with vertical flow channels at $0^{\circ}$ ).

Figure 2 shows the mesh of the fluidized bed designs incorporating flow distributors with straight and angular flow channels. The mesh incorporates tetrahedral cells, which facilitates clustering of cells in select regions of the flow. We built a Perspex prototype that enabled experimental validation of the simulation using calcium alginate beads (with differing sphericities), described in Section 2.3.

\subsection{CFD Validation}

As in Delafosse et al. (2018) the Eulerian-Eulerian Granular two-phase model was validated against the empirically determined minimum microcarrier suspension condition: which in this case is the minimum fluidization velocity. As mentioned in Section 2.2, a preliminary Perspex prototype was designed to experimentally validate the CFD results. An experimental scenario of using $3.0 \mathrm{~mm}$ calcium alginate beads within a Perspex vessel using water as the carrier fluid. Calcium alginate beads were selected for ease of visualisation. Figure 3Error! Reference source not found.a displays a plot of the particle bed height in the vessel at increasing liquid superficial velocities.

The experimentally determined minimum fluidization velocity was compared to the value calculated using the Ergun equation and the superficial velocity at which fluidization occurs within the CFD model as described above. The results are shown in Figure $3 \mathrm{~b}$. The particle sphericity can influence the minimum fluidization velocity, for this reason, particles with an average index of sphericity of 1.0111 (measured via image processing using MATLAB with standard deviation of 0.002 ) were used to obtain the experimental $\mathrm{V}_{\mathrm{mf}}$.

CFD analysis of the modelled calcium alginate beads using traditional and swirling flow distributors are presented (Figure 5). To biologically validate the novel swirling flow distributor design $\left(45^{\circ}\right.$ angle flow channels), an autoclavable prototype fluidized bed was developed (Section 2.6) and commercial Cytodex 1 microcarriers were used to culture HTERT MSCs within the bioreactor (Section 3). 


\subsection{Bioreactor Culture Protocol}

The bioreactor fluidic set-up is illustrated in Figure 4. The Cytodex 1 microcarriers were seeded at 5,000 cells $/ \mathrm{cm}^{2}\left(2.5 \times 10^{7}\right.$ cells in total). The media consisted of DMEM with $4.0 \mathrm{mM}$ of L-glutamine, $4.5 \mathrm{~g} / \mathrm{L}$ glucose and $0.11 \mathrm{~g} / \mathrm{L}$ of sodium pyruvate (Sigma-Aldrich, Gillingham, UK), supplemented with $1 \%$ $\mathrm{v} / \mathrm{v}$ antibiotic/antimycotic (10,000 units penicillin, $10 \mathrm{mg}$ streptomycin and $25 \mu \mathrm{g}$ amphotericin B per $\mathrm{mL})$. The bioreactor was incubated at $37^{\circ} \mathrm{C}$ and the headspace aerated with air $(5 \% \mathrm{CO} 2)$ at $100 \mathrm{~mL} / \mathrm{min}$. Following seeding, microcarrier and cell mixing was achieved by intermittent fluidization at a superficial velocity of $1.5 \mathrm{~mm} / \mathrm{s}$ : The cell culture was pumped out and fluidized by inward flow for 100 pump revolutions every 5 mins from day 0 to day 1 . The swirling flow distributor enabled axial and radial mixing of the carriers, cells, nutrients and metabolites. A 6-day cell culture was performed in the prototype bioreactor for biological validation. On day 1 (following inoculation), agitation was achieved by upward and downward flow (100 pump revolutions) every $5 \mathrm{mins}$ at $\mathrm{V}_{\text {superficial }}=1.5 \mathrm{~mm} / \mathrm{s}$. With a total media volume of $600 \mathrm{~mL}$, a $200 \mathrm{~mL}$ media exchanged was conducted on day 3 and day 5 of the cell culture. Cell samples for counting were taken on days 1 (to ascertain cell attachment efficiency), 3 and 6.

\subsection{Culture and Sub-Culture}

Green Fluorescence Protein (GFP)-producing human MSCs were kindly provided by the Department of Paediatrics and Adolescent Medicine, LKS Faculty of Medicine, The University of Hong Kong. Dulbecco's Modified Eagle's Medium (DMEM) containing Pyruvate, L-glutamine and glucose (1.0 g/L) (Lonza, UK) and supplemented with $10 \% \mathrm{v} / \mathrm{v}$ foetal bovine serum (Lonza, UK) and $1 \%$ Penicillin/Streptomycin (Sigma, UK), was prepared for the cell growth media. Monolayer expansion of the cells was prepared in T175 (175 $\mathrm{cm}^{2}$ area) T-flasks, using $35 \mathrm{~mL}$ of complete growth medium. The cells were incubated at $37^{\circ} \mathrm{C}$ in a humidified incubator aerated with a blend of air with $5 \% \mathrm{CO}_{2}$. The cells were subsequently passaged once confluent (>80\%). The passage process involved first washing the cells twice with $15 \mathrm{~mL}$ of $\mathrm{Ca}^{2+}$ and $\mathrm{Mg}^{2+}$-free phosphate buffer saline (PBS, Lonza, UK). The cells were then incubated in $15 \mathrm{~mL}$ of $0.25 \%$ Trypsin/EDTA for 10 minutes, to facilitate cell detachment. The enzyme within the trypsin-cell solution was quenched by adding $15 \mathrm{~mL}$ of fresh growth medium (as prepared above). The cell suspension was centrifuged at $1000 \mathrm{~g}$ for 5 minutes at room temperature and the supernatant aspirated and discarded. The pellet was then re-suspended in $5 \mathrm{~mL}$ of fresh growth medium.

Cytodex 1 microcarriers (GE Healthcare, USA) were used to conduct initial feasibility studies within the prototype bioreactor. The use of microcarriers facilitate an initial proof-of-concept of the efficiency of the flow distributor to engender uniform inoculation. Cytodex 1 microcarriers were first immersed in PBS for 3 hours to allow for swelling, then washed three times with fresh PBS. They were sterilised 
through autoclaving $\left(121^{\circ} \mathrm{C}, 1 \mathrm{bar}, 20\right.$ minutes). Microcarriers were maintained in culture medium for at least 24 hours before cell seeding.

\subsection{Biological Analysis Methods}

\section{Trypan Blue Exclusion Method}

The viable cell count was performed using a Countess ${ }^{\mathrm{TM}}$, via the trypan blue exclusion method. $10 \mu \mathrm{L}$ of cells were mixed with $10 \mu \mathrm{L}$ of trypan blue. $10 \mu \mathrm{L}$ of the resulting cell solution was pipetted into each of two chambers within the Countess ${ }^{\mathrm{TM}}$ slide. The average cell count was determined from the counts from three Countess ${ }^{\mathrm{TM}}$ chamber slides (thus average from 6 measurements).

\section{Crystal Violet Dye}

A crystal violet dye $\left(\mathrm{CVD}^{\mathrm{TM}}\right.$, CESCO) staining kit was used to determine the total nuclei count within the microcarrier-based cell culture platforms. $1 \mathrm{~mL}$ of $\mathrm{CVD}^{\mathrm{TM}}$ containing citric acid, detergent and crystal violet, to lyse the cells and stain the nuclei, is first added to a $1 \%$ volume sample of colonised microcarriers (separated from media). The CVD-microcarrier sample is vortex mixed for 30 seconds and incubated at $37^{\circ} \mathrm{C}$ for one hour. The sample is then vortex mixed a second time for 30 seconds and the nuclei concentration counted using a haemocytometer.

\section{Lactate and Glucose Measurements}

To monitor lactate and glucose, media samples were taken on days $0,3,5$ and 6 of the fluidized bed and bottle control cell cultures. A NovaBiomedical LactatePlus reader and GluCell ${ }^{\mathrm{TM}}$ was used to determine the lactate and glucose concentrations, respectively, within the samples.

\section{Fluorescence Microscopy}

Images of the GFP produced by the MSCs were acquired with fluorescence microscopy (Eclipse Ti, Nikon, Japan) to visualize cell membranes and therefore cell attachment, spreading and confluence state.

\section{Results \& Discussion}

\subsection{Swirling Flow Distributor}

Few studies have considered the flow distributor design in detail [29], [41], although Ouyang and Levenspiel (1986) were the first to introduce the concept of swirling fluidization using gas with overlapping circle segments. With additive manufacturing, angled individual flow channels can be developed, reducing the risk of particle elutriation and facilitating greater complexity over the individual flow structures induced by the flow distributor. 
The preliminary flow distributor designs were initially assessed using CFD assuming uniform flow inlet prior to the distributor plate. To assess the effectiveness of swirling fluidization for both radial and axial movement of particles, the velocity vector of the solid phase was modelled under steady state conditions. Figure 5 shows the velocity vectors of the solid phase for both distributor designs: the solid phase (calcium alginate) velocity vectors in the radial (x) and axial (z) direction are coloured by the $\mathrm{x}$ and $\mathrm{z}$ direction of velocity, at $\mathrm{V}_{\text {superficial }}=0.002 \mathrm{~ms}^{-1}$. This is below the minimum fluidization rate for the calcium alginate beads that are modelled. Uniform flow inlet was assumed for this simulation to assess the relative difference between the two designs. Velocities of up to 0.01 and $0.02 \mathrm{~m} / \mathrm{s}$ were noted in the conventional straight and angular flow distributor, respectively. Furthermore, a much greater proportion of the solid phase was in flux under swirling fluidization. The simulation illustrated significantly enhanced radial and axial movement of the fluidized solid phase, which is pertinent for effective distribution of colonised and non-colonised particles.

The angle flow channels induced movement of particles at a reduced carrier fluid superficial velocity. With the traditional flow distributor (exhibiting vertical flow channels), peak $\mathrm{u}_{\mathrm{x}}$ and $\mathrm{u}_{\mathrm{z}}$ solid phase velocities of $0.01 \mathrm{~ms}^{-1}$ and $0.01 \mathrm{~ms}^{-1}$ are noted. Whereas angled flow channels at $45^{\circ}$ relative to the horizontal plate induced $u_{x}$ and $u_{z}$ solid phase velocities of up to $0.02 \mathrm{~ms}^{-1}$ and $0.02 \mathrm{~ms}^{-1}$. This is a result of the solid phase momentum that is preserved by the circular nature of the fluid flow, in addition to the reduce force required to move the solid phase in a non-vertical direction. In a separate study within our laboratory, a particle tracking study was performed on swirling flow distributor designs in a nonbiological fluidized bed [43]. Radial particle movement induced by flow distributors incorporating $0^{\circ}$, $15^{\circ}, 30^{\circ}$ and $45^{\circ}$ angled flow channels was assessed. Angled flow channels at $45^{\circ}$, demonstrated superior radial movement of particles under fluidization (compared to the other designs). Therefore, a $45^{\circ}$ swirling flow distributor was selected in the autoclavable bioreactor prototype developed for biological validation, in the study presented.

\subsection{Bioreactor Biological Validation}

\subsubsection{Inoculation}

The geometric features of a given scaffold for adherent cell expansion has an important influence over the attachment efficiency, cell concentration and yield upon harvest. Non-porous spherical particles such as the Cytodex (GE Healthcare) and Plastic (SoloHill) microcarriers have been extensively investigated in academia and industry, primarily due to their high surface area to volume ratios and applicability for use in conventional stirred bioreactors. Porous carriers (e.g. ESCO's fibrous Bionoc II and GE's macroporous Cytopore) offer even greater surface area densities, however cell distribution within the available surface area, in addition to reduced accessibility to nutrients within the pores, are drawbacks for such systems. The surface structure is however pertinent to cell attachment, with Li et al. (2016) demonstrating that cells preferentially attach to wrinkled as opposed to smooth surfaces. 
Inoculation is for many reasons a critical step in the expansion of autologous mesenchymal stem cell therapy, not least due to the limited number of cells that are accessible from the patient. Stirred tank bioreactors are the dominant production platform for both adherent and suspension cells. Rafiq et al. (2013) seeded bone marrow derived MSCs onto Plastic P-102L (Solohill Engineering Inc., USA) microcarriers at a concentration of 6,000 cells $/ \mathrm{cm}^{2}$, allowing the culture to remain static for 18 hours. After inoculation the culture was agitated continuously at the $\mathrm{N}_{\mathrm{js}}$ (the minimum impeller speed required to suspend the microcarriers). The carriers were agitated in order to expose the cells to mass transfer of nutrients to and metabolites from the cells [8]. Inoculation of packed bed bioreactors offer a different problem of cell distribution. In order to distribute cells seeded onto a packed bed of polystyrene scaffolds ( $1.5 \mathrm{~cm}$ diameter and $7.5 \mathrm{~cm}$ in length), Osiecki et al. (2015) first injected GFP-mMSCs (1,000 cells $/ \mathrm{cm}^{2}$ ) onto a scaffold and then placed the cylindrical vessel onto a tube rocker roller for 10 mins at $5 \mathrm{rpm}$, with a subsequent 5 minutes of rest (repeated for 3 hours). Studies have shown a dependency on spatial distribution during the culture of chondrocytes on a polymer scaffold due to metabolite and nutrient concentration gradients [46], with uniform distribution being attributed to enhanced cell functionality [47].

The two primary methods of cell seeding are static (first culture step in a static vessel or in the bioreactor without flow perfusion) and dynamic (flow perfusion starts immediately after inoculation). A number of studies have shown significant differences in seeding efficiency when comparing static and dynamic regimes: For chondrocytes seeded onto Polyactive foams, Wendt et al. (2003) noted attachment efficiencies of $75 \pm 6 \%, 57 \pm 5 \%$ and $55 \pm 8 \%$ for perfusion, static and spinner flask systems respectively. A dynamic depth-filtration seeding method was developed to seed trophoblast-like $\mathrm{ED}_{27}$ cells upon nonwoven polyethylene terephthalate (PET) carriers, with seeding efficiencies $<40 \%$ under static conditions and up to $80 \%$ using the dynamic depth-filtration protocol [49]. Thus, fluid flow was shown to be pertinent to cell seeding, given the need for cells to make contact with the scaffold. However, moving fluid that is too fast can be detrimental to cell attachment.

Figure 6 displays fluorescent microscopy images of MSCs attached to Cytodex 1 microcarriers following inoculation under static (glass bottle) and semi-static conditions, i.e. intermittent fluidization starting immediately after microcarriers and cells insertion in the bioreactor vessel. Comparison of the two inoculation procedures showed that the cells were more evenly distributed and had a better characteristic fibroblast morphology under semi-static conditions than static conditions. Static inoculation of MSCs on Cytodex 1 microcarriers in a glass bottle exhibited an attachment efficiency of $50 \%$, which is comparable to the $57 \%$ seeding efficiency of human bone marrow stromal cells reported in literature [50], whereas the semi-static inoculation provided an attachment efficiency of $95 \%$. As expected, this can be attributed to the cells having had access to a greater portion of the microcarriers when intermittently agitated. Of course, the cells should also be given adequate time to attach. Thus, achieving a balance between surface accessibility and attachment time is important. 


\subsubsection{Cell Expansion}

On day 1, agitation was commenced by performing flow perfusion every 5 mins at $V_{\text {superficial }}=1.5 \mathrm{~mm} / \mathrm{s}$. Figure 7 a shows the cell fold expansion on days 0,3 and 6 of the culture. Noticeable cell growth commenced from day 3 ; this lag likely due to the antibiotic/antimycotic cocktail used to prepare the growth media. However, the lag phase correlates with observations of MSCs grown on Cytodex microcarriers. The growth rate of $\mu=0.012 \mathrm{hr}^{-1}$ within the fluidized bed (during the exponential phase) was comparable with values noted in the literature $\left(\mu=0.006\right.$ to $\left.0.014 \mathrm{hr}^{-1}\right)$ [1], [8], [51]. One method of increasing cell specific growth rates could be optimising the cell seeding density: Studies have shown that the seeding density (cells $/ \mathrm{cm}^{2}$ ) significantly influences fold expansion [1], [52]-[54] with values below 2000 cells $/ \mathrm{cm}^{2}$ increasing fold expansion. However, this needs to be balanced with the total cells available from the patient and required at harvest.

Fluorescence microscopy images of MSCs attached to Cytodex 1 microcarriers at days 3 and 6 postinoculation are shown in Figure 7b. During this phase of the culture, the cells expanded by 2.4-fold. This highlights the importance of minimising the lag phase as the cells are able to adapt then to the in vitro dynamic culture environment. A lactate yield of 1.2 moles lactate per mole of glucose was obtained between days 3 and 6 of the fluidized bed bioreactor culture and indicated that the glucose conversion to adenosine triphosphate (ATP) occurred mostly under aerobic glycolysis [55]. A lactate yield of 2 $\mathrm{mol} / \mathrm{mol}$ would indicate anaerobic glycolysis, as all the glucose would be converted to lactate. Therefore, access to oxygen was not limited within the fluidized bed bioreactor, as expected thanks to the flow perfusion. Aerobic glycolysis is indeed the more effective energy production method, producing 30-38 moles of ATP per mole of glucose, compared to the 2 moles of ATP per mole of glucose in anaerobic glycolysis [55].

\section{Conclusions}

A fluidized bed bioreactor was designed and manufactured for mesenchymal stem cell expansion. Computational fluid dynamics and additive manufacturing were combined effectively to introduce and optimise a novel angular flow distributor $\left(45^{\circ}\right)$. MSCs inoculation and cell expansion procedures were investigated in a proof-of-concept study utilising an autoclavable prototype. Commercial microcarriers, Cytodex 1, were used to illustrate functional application of the bioreactor. The bespoke fluidized bed employed novel flow distributor technology to enhance mixing successfully, leading to increased cell attachment and proliferation compared to static culture on the same scaffold. This approach opens the possibility for bespoke flow distributor for a variety of requirements where precise flow regimes are required. This was applied to good effect to investigate the impact of static and non-static inoculation procedures on cell attachment. The ability of the bioreactor to enable expansion using commercially available microcarriers, demonstrating comparable cell growth statistics, increased its functionality. 
The next stage of development is to design and construct a fully 3D-printed single-use prototype, to be integrated into an automated cell expansion unit.

The computational and additive manufacturing approach presented could revolutionise bioreactor design. However, there are limitations in the work presented. The Eulerian-Eulerian approach is not amenable to estimating the shear stresses exerted on micro and macrocarriers surface: A CFD-DEM approach would be more suitable for such measurements [56]. However, the rapid prototyping capacity of 3D printers, means that complex designs can be fabricated cost effectively (current price of a Form $23 \mathrm{D}$ printer of circa. \$3000) and expeditiously (designs can be fabricated in hours).

\section{Nomenclature}

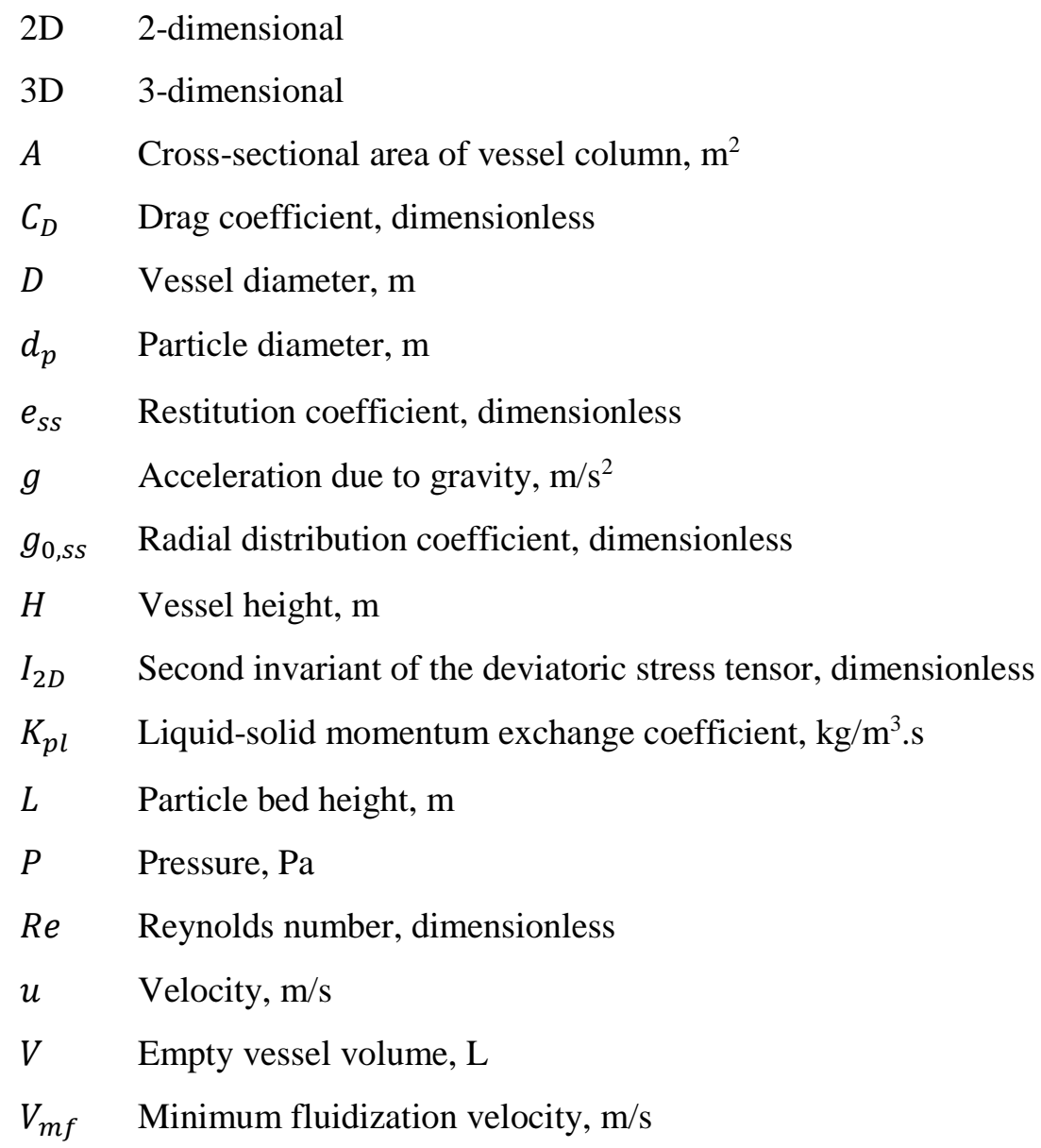

\section{Greek Symbols}

$\varepsilon \quad$ Voidage, dimensionless

$\lambda_{s} \quad$ Bulk viscosity, $\mathrm{kg} / \mathrm{m} . \mathrm{s}$

$\varphi \quad$ Particle sphericity, dimensionless

$\Theta_{p} \quad$ Granular temperature, $\mathrm{m}^{2} / \mathrm{s}^{2}$

$\rho \quad$ Density, $\mathrm{kg} / \mathrm{m}^{3}$ 
$\begin{array}{ll}\mu & \text { Viscosity, } \mathrm{kg} / \mathrm{m} . \mathrm{s} \\ \mu_{p, f r i} & \text { Frictional viscosity, } \mathrm{kg} / \mathrm{m} . \mathrm{s}\end{array}$

\author{
Subscripts \\ $l \quad$ Liquid \\ mf Minimum fluidization \\ $p \quad$ Particle \\ $s \quad$ Solids
}

\title{
Acknowledgments
}

This work was supported by funding provided by China Regenerative Medicine International (CRMI) Limited.

\section{References}

[1] C. J. Hewitt, K. Lee, A. W. Nienow, R. J. Thomas, M. Smith, and C. R. Thomas, "Expansion of human mesenchymal stem cells on microcarriers.," Biotechnol. Lett., vol. 33, no. 11, pp. 2325-35, Nov. 2011.

[2] S. M. Badenes, T. G. Fernandes, C. A. V. Rodrigues, M. M. Diogo, and J. M. S. Cabral, "Scalable Expansion of Human-Induced Pluripotent Stem Cells in Xeno-Free Microcarriers," Methods Mol. Biol., vol. 1283, pp. 23-29, 2015.

[3] N. Escacena, E. Quesada-hernández, V. Capilla-gonzalez, B. Soria, and A. Hmadcha, "Bottlenecks in the Efficient Use of Advanced Therapy Medicinal Products Based on Mesenchymal Stromal Cells," Stem Cells Int., vol. 2015, 2015.

[4] T. A. Grein, J. Leber, M. Blumenstock, F. Petry, T. Weidner, D. Salzig, and P. Czermak, "Multiphase mixing characteristics in a microcarrier-based stirred tank bioreactor suitable for human mesenchymal stem cell expansion," Process Biochem., vol. 51, no. 9, pp. 1109-1119, 2016.

[5] K. M. Panchalingam, S. Jung, L. Rosenberg, and L. A. Behie, "Bioprocessing strategies for the large-scale production of human mesenchymal stem cells: a review," Stem Cell Res. Ther., vol. 6, no. 1, p. 225, 2015.

[6] R. Brandenberger, S. Burger, A. Campbell, T. Fong, E. Lapinskas, and J. A. Rowley, "Cell Therapy Bioprocessing,” Biopharm Int., vol. 9, no. 3, pp. S30-S37, 2011. 
[7] J. Rowley, E. Abraham, A. Campbell, H. Brandwein, and S. Oh, "Meeting Lot-Size Challenges of Manufacturing Adherent Cells for Therapy," Bioprocess Int., vol. 10, pp. 16-22, 2012.

[8] Q. A. Rafiq, K. M. Brosnan, K. Coopman, A. W. Nienow, and C. J. Hewitt, "Culture of human mesenchymal stem cells on microcarriers in a 51 stirred-tank bioreactor.," Biotechnol. Lett., vol. 35, no. 8, pp. 1233-45, Aug. 2013.

[9] Y.-K. Wang and C. S. Chen, "Cell adhesion and mechanical stimulation in the regulation of mesenchymal stem cell differentiation.," J. Cell. Mol. Med., vol. 17, no. 7, pp. 823-32, 2013.

[10] P. J. Hanley, Z. Mei, M. Da Graca Cabreira-Hansen, M. Klis, W. Li, Y. Zhao, A. G. Durett, X. Zheng, Y. Wang, A. P. Gee, and E. M. Horwitz, "Manufacturing mesenchymal stromal cells for phase i clinical trials," Cytotherapy, vol. 15, no. 4, pp. 416-422, 2013.

[11] V. Jain, L. Kalo, D. Kumar, H. J. Pant, and R. K. Upadhyay, "Experimental and numerical investigation of liquid-solid binary fluidized beds: Radioactive particle tracking technique and dense discrete phase model simulations," Particuology, 2017.

[12] C. R. Carlos and J. F. Richardson, "Solids movement in liquid fluidised beds - I Particle velocity distribution," Chem. Eng. Sci., vol. 23, no. 8, pp. 813-824, 1968.

[13] L. S. Fan, "Summary paper on fluidization and transport phenomena," Powder Technol., vol. 88, no. 3, pp. 245-253, 1996.

[14] J. N. Warnock and M. Al-Rubeai, "Bioreactor systems for the production of biopharmaceuticals from animal cells.," Biotechnol. Appl. Biochem., vol. 45, no. Pt 1, pp. 112, 2006.

[15] S. R. Pollack, D. F. Meaney, E. M. Levine, M. Litt, and E. D. Johnston, "Numerical Model and Experimental Validation of Microcarrier Motion in a Rotating Bioreactor," Tissue Eng., vol. 6, no. 5, pp. 519-530, 2000.

[16] P. Sucosky, D. F. Osorio, J. B. Brown, and G. P. Neitzel, "Fluid mechanics of a spinner-flask bioreactor.," Biotechnol. Bioeng., vol. 85, no. 1, pp. 34-46, Jan. 2004.

[17] H. Singh, S. H. Teoh, H. T. Low, and D. W. Hutmacher, "Flow modelling within a scaffold under the influence of uni-axial and bi-axial bioreactor rotation," J. Biotechnol., vol. 119, pp. 181-196, 2005.

[18] J. Dusting and S. Balabani, "Mixing in a Taylor-Couette reactor in the non-wavy flow regime," Chem. Eng. Sci., vol. 64, no. 13, pp. 3103-3111, Jul. 2009.

[19] A. O. O. Odeleye, D. T. J. Marsh, M. D. Osborne, G. J. Lye, and M. Micheletti, "On the fluid 
dynamics of a laboratory scale single-use stirred bioreactor," Chem. Eng. Sci., vol. 111, pp. 299-312, May 2014.

[20] D. W. Hutmacher and H. Singh, "Computational fluid dynamics for improved bioreactor design and 3D culture," Trends Biotechnol., vol. 26, no. 4, pp. 166-172, 2008.

[21] D. Massai, G. Isu, D. Madeddu, G. Cerino, A. Falco, C. Frati, D. Gallo, M. A. Deriu, G. Falvo, D. U. Labate, F. Quaini, A. Audenino, and U. Morbiducci, "A Versatile Bioreactor for Dynamic Suspension Cell Culture. Application to the Culture of Cancer Cell Spheroids," PLoS One, pp. 1-16, 2016.

[22] G. Isu, U. Morbiducci, G. De Nisco, C. Kropp, A. Marsano, M. A. Deriu, R. Zweigerdt, A. Audenino, and D. Massai, "Modeling methodology for defining a priori the hydrodynamics of a dynamic suspension bioreactor. Application to human induced pluripotent stem cell culture," J. Biomech., vol. 94, pp. 99-106, 2019.

[23] K. SC, J. V, S. C, E. D, B. S, van den B. C, and E. R., "Fluid flow and cell proliferation of mesenchymal adipose-derived stem cells in small-scale, stirred, single use bioreactors," Chem. Ing. Tech., vol. 85, pp. 95-102, 2012.

[24] F. Consolo, C. Bariani, A. Mantalaris, F. Montevecchi, A. Redaelli, and U. Morbiducci, "Computational modeling for the optimization of a cardiogenic 3D bioprocess of encapsulated embryonic stem cells.," Biomech. Model. Mechanobiol., vol. 1-2, pp. 261-277, 2012.

[25] P. Connick, M. Kolappan, C. Crawley, D. J. Webber, R. Patani, A. W. Michell, M. Q. Du, S. L. Luan, D. R. Altmann, A. J. Thompson, A. Compston, M. A. Scott, D. H. Miller, and S. Chandran, "Autologous mesenchymal stem cells for the treatment of secondary progressive multiple sclerosis: An open-label phase 2a proof-of-concept study," Lancet Neurol., vol. 11, no. 2 , pp. 150-156, 2012.

[26] M. Duijvestein, A. C. W. Vos, H. Roelofs, M. E. Wildenberg, B. B. Wendrich, H. W Verspaget, E. M. C. Kooy-Winkelaar, F. Koning, J. J. Zwaginga, H. H. Fidder, A. P. Verhaar, W. E. Fibbe, G. R. van den Brink, and D. W. Hommes, “Autologous bone marrow-derived mesenchymal stromal cell treatment for refractory luminal Crohn's disease: results of a phase I study.," Gut, vol. 59, pp. 1662-1669, 2010.

[27] Y.-M. Chen, "Fundamentals of a centrifugal fluidized bed," AIChE J., vol. 33, no. 5, pp. 722728, May 1987.

[28] A. Rao, J. S. Curtis, B. C. Hancock, and C. Wassgren, "The Effect of Column Diameter and Bed Height on Minimum Fluidization Velocity," Am. Inst. Chem. Eng., vol. 56, no. 9, pp. 2304-2311, 2010. 
[29] M. Wormsbecker, T. S. Pugsley, and H. Tanfara, "The Influence of Distributor Design on Fluidized Bed Dryer Hydrodynamics,” 12th Int. Conf. Fluid. New Horizons Fluid. Eng., pp. 814-822, 2007.

[30] D. W. Levine, D. I. C. Wang, and W. G. Thilly, "Optimization of growth surface parameters in microcarrier cell culture,” Biotechnol. Bioeng., vol. 21, no. 5, pp. 821-845, May 1979.

[31] T. B. L. Nguyen, A. O. O. Odeleye, C.-Y. Chui, T. Baudequin, Z. Cui, and H. Ye, "Development of thermo-responsive polycaprolactone macrocarriers conjugated with Poly $(\mathrm{N}$ isopropyl acrylamide) for cell culture," Sci. Rep., vol. In press, 2019.

[32] D. C. Sau and K. C. Biswal, "Computational fluid dynamics and experimental study of the hydrodynamics of a gas-solid tapered fluidized bed," Appl. Math. Model., vol. 35, no. 5, pp. 2265-2278, 2011.

[33] S. Roy and M. P. Dudukovic, "Flow Mapping and Modeling of Liquid - Solid Risers," Ind. Eng. Chem Res, vol. 40, pp. 5440-5454, 2001.

[34] J. Ma and M. Srinivasa, "Particulate modeling in Ansys CFD," 2008 Int. ANSYS Conf., pp. 130, 2008.

[35] D. Gidaspow, "Multiphase flow and fluidization: continuum and kinetic theory descriptions," Acad. Press Inc, Bost., 1994.

[36] L. Fan, J. R. Grace, and N. Epstein, "CFD Simulation of a Liquid-Solid Fluidized Bed of Binary Particles," in The 13th International Conference on Fluidization - New Paradigm in Fluidization Engineering, 2010, pp. 1-9.

[37] C. K. K. Lun, S. B. Savage, D. J. Jeffrey, and N. Chepurniy, "Kinetic theories for granular flow: inelastic particles in Couette flow and slightly inelastic particles in a general flowfield," J. Fluid Mech., vol. 140, pp. 223-256, 1984.

[38] J. Lundberg and B. M. Halvorsen, "A review of some existing drag models describing the interaction between phases in a bubbling fluidized bed," in Proc. 49th Scand. Conf. Simulation and Modeling, 2008, pp. 1-8.

[39] D. G. Schaeffer, "Instability in the evolution equations describing incompressible granular flow," J. Differ. Equ., vol. 66, no. 1, pp. 19-50, 1987.

[40] A. Delafosse, C. Loubière, S. Calvo, D. Toye, and E. Olmos, "Solid-liquid suspension of microcarriers in stirred tank bioreactor - Experimental and numerical analysis .," Chem. Eng. Sci., 2018.

[41] Z. Garncarek, L. Przybylski, J. S. M. Botterill, and C. J. Broadbent, "A quantitative assessment 
of the effect of distributor type on particle circulation," Powder Technol., vol. 91, no. 3, pp. 209-216, 1997.

[42] F. Ouyang and O. Levenspiel, "Spiral Distributor for Fluidized Beds," Ind. Eng. Chem. Process Des. Dev., vol. 25, pp. 504-507, 1986.

[43] A. O. O. Odeleye, C.-Y. Chui, L. Nguyen, A. A. Castrejón-pita, H. Ye, and Z. Cui, "Chemical Engineering Research and Design On the use of 3D-printed flow distributors to control particle movement in a fluidized bed Akinlolu Oyekunle Oluseun Odeleye a, Chih-Yao Chui a , Linh Nguyen a ," Chem. Eng. Res. Des., vol. 140, pp. 194-204, 2018.

[44] M. Li, D. Joung, B. Hughes, S. D. Waldman, J. A. Kozinski, and D. K. Hwang, "Wrinkling Non-Spherical Particles and Its Application in Cell Attachment Promotion," Sci. Rep., vol. 6, p. 30463, 2016.

[45] M. J. Osiecki, T. D. Michl, B. Kul Babur, M. Kabiri, K. Atkinson, W. B. Lott, H. J. Griesser, and M. R. Doran, "Packed Bed Bioreactor for the Isolation and Expansion of PlacentalDerived Mesenchymal Stromal Cells,” PLoS One, vol. 10, no. 12, pp. 1-18, 2015.

[46] C. J. Galban and B. R. Locke, "Effects of spatial variation of cells and nutrient and product concentrations coupled with product inhibition on cell growth in a polymer scaffold," Biotechnol. Bioeng., vol. 64, no. 6, pp. 633-643, 1999.

[47] A. L. Olivares and D. Lacroix, "Simulation of cell seeding within a three-dimensional porous scaffold: a fluid-particle analysis.," Tissue Eng. Part C. Methods, vol. 18, no. 8, pp. 624-31, 2012.

[48] D. Wendt, a Marsano, M. Jakob, M. Heberer, and I. Martin, "Oscillating perfusion of cell suspensions through three-dimensional scaffolds enhances cell seeding efficiency and uniformity.," Biotechnol. Bioeng., vol. 84, no. 2, pp. 205-14, Oct. 2003.

[49] Y. Li, T. Ma, D. A. Kniss, L. C. Lasky, and S. T. Yang, "Effects of filtration seeding on cell density, spatial distribution, and proliferation in nonwoven fibrous matrices," Biotechnol. Prog., vol. 17, no. 5, pp. 935-944, 2001.

[50] D. Schop, R. van Dijkhuizen-Radersma, E. Borgart, F. W. Janssen, H. Rozemuller, and 5 H-J. Prins4 and J. D. de Bruijn1, 2, "Expansion of human mesenchymal stromal cells on microcarriers: growth and metabolism," J. Tissue Eng. Regen. Med., vol. 4, pp. 131-140, 2010.

[51] T. R. J. Heathman, V. A. M. Glyn, A. Picken, Q. A. Rafiq, K. Coopman, A. W. Nienow, B. Kara, and C. J. Hewitt, "Expansion, Harvest and Cryopreservation of Human Mesenchymal 
Stem Cells in a Serum-free Microcarrier Process," Biotechnol. Bioeng., vol. 112, no. 8, pp. 1696-1707, 2015.

[52] C. Bartmann, E. Rohde, K. Schallmoser, P. Pürstner, and G. Lanzer, "Two steps to functional mesenchymal stromal cells for clinical application," Transplant. Cell. Eng., vol. 47, no.

August, pp. 1426-1435, 2007.

[53] B. Neuhuber, S. A. Swanger, L. Howard, A. Mackay, and I. Fischer, "Effects of plating density and culture time on bone marrow stromal cell characteristics," Exp. Hematol., vol. 36, pp. 1176-1185, 2008.

[54] S. K. Both, A. J. C. Van Der Muijsenberg, C. A. Van Blitterswijk, J. De Boer, and J. D. De Bruijn, "A Rapid and Efficient Method for Expansion of Human Mesenchymal Stem Cells," Tissue Eng., vol. 13, no. 1, pp. 3-10, 2007.

[55] M. W. Glacken, "Catabolic Control of Mammalian Cell Culture," Bio/Technology, vol. 6, no. 9, pp. 1041-1050, 1988.

[56] Z. Huang, A. O. O. Odeleye, H. Ye, Z. Cui, and A. Yang, "Fluid dynamic characterization of a fluidized-bed perfusion bioreactor with CFD-DEM simulation," J. Chem. Technol. Biotechnol, vol. 93, pp. 2316-2330, 2018.

\section{Figures}
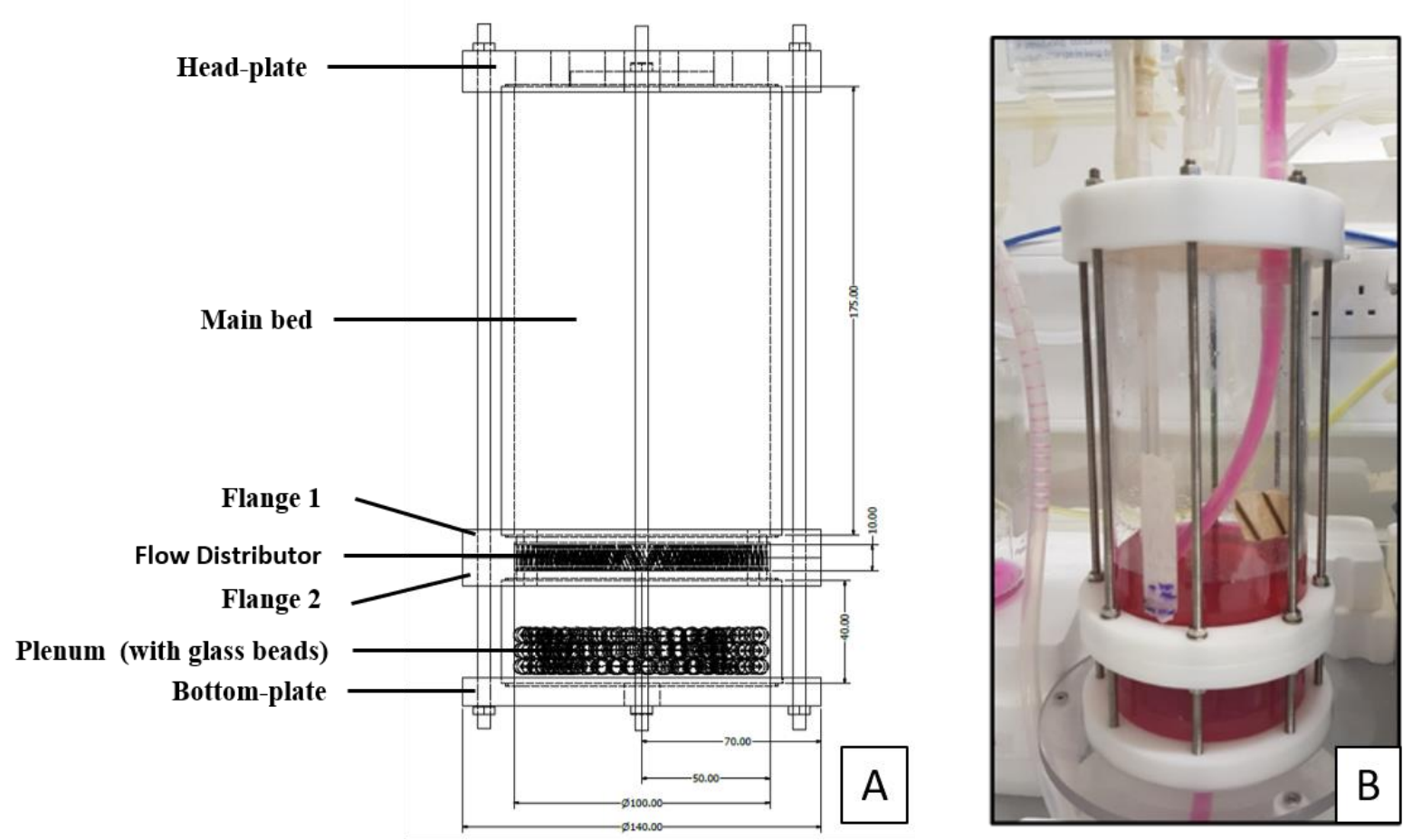
Figure 1: a) Technical drawing of the prototype bioreactor (dimensions in millimeters) and b) image of the prototype bioreactor.

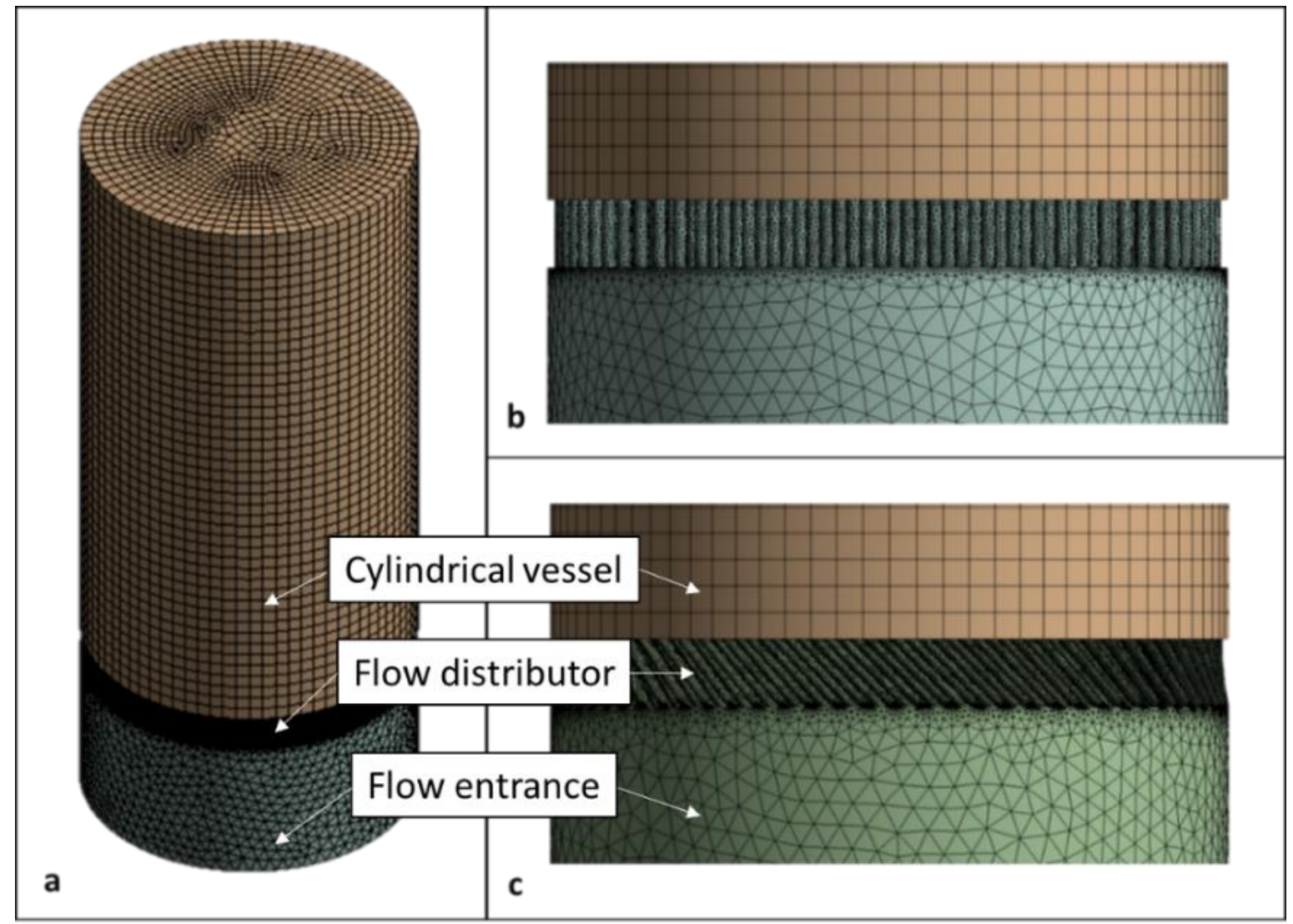

Figure 2: CFD mesh of the simulated bioreactor model fluid phase showing: a) the whole cylindrical vessel b) close up of a flow distributor with $0^{\circ}$ straight flow channels and c) close up of a flow distributor with $45^{\circ}$ angular flow channels 


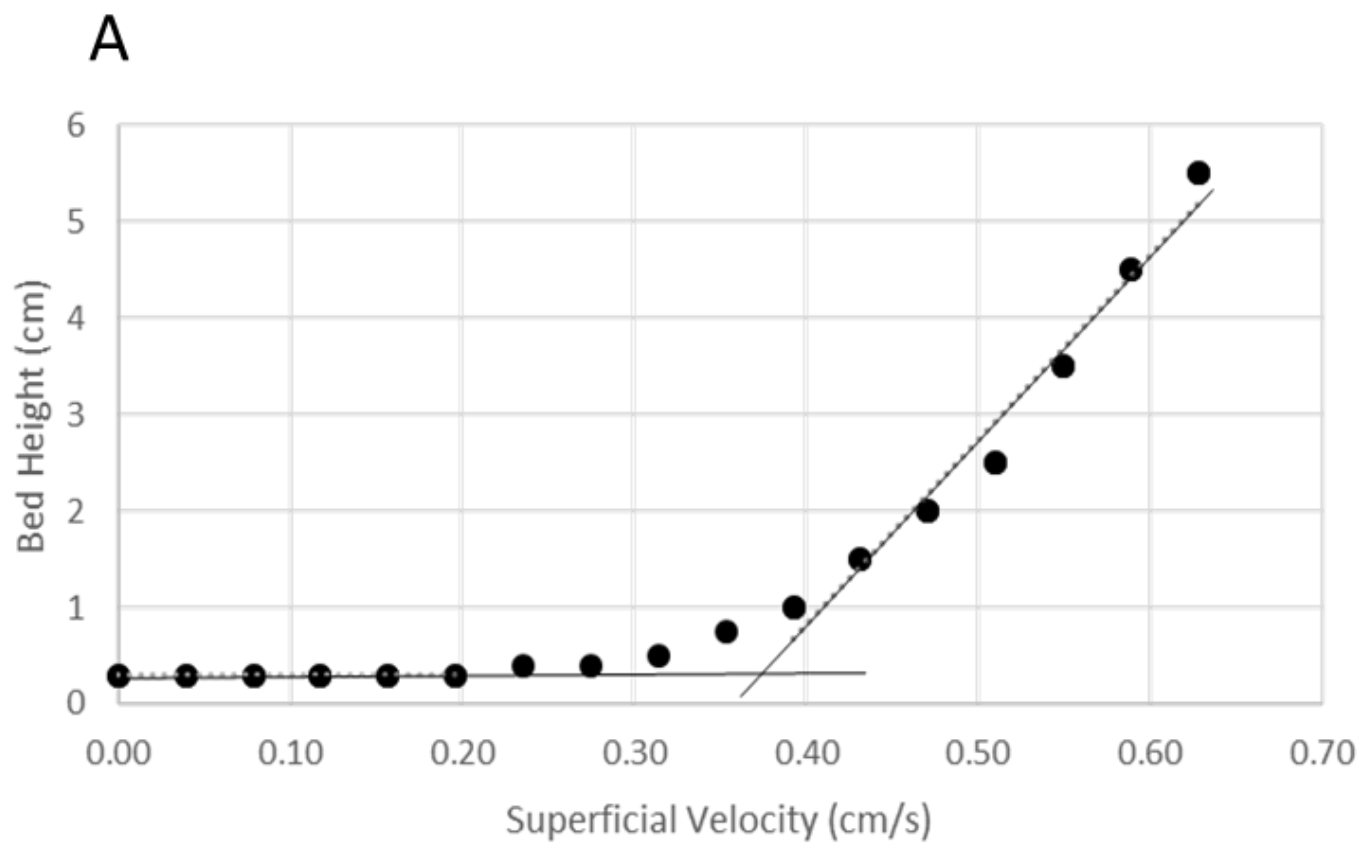

B

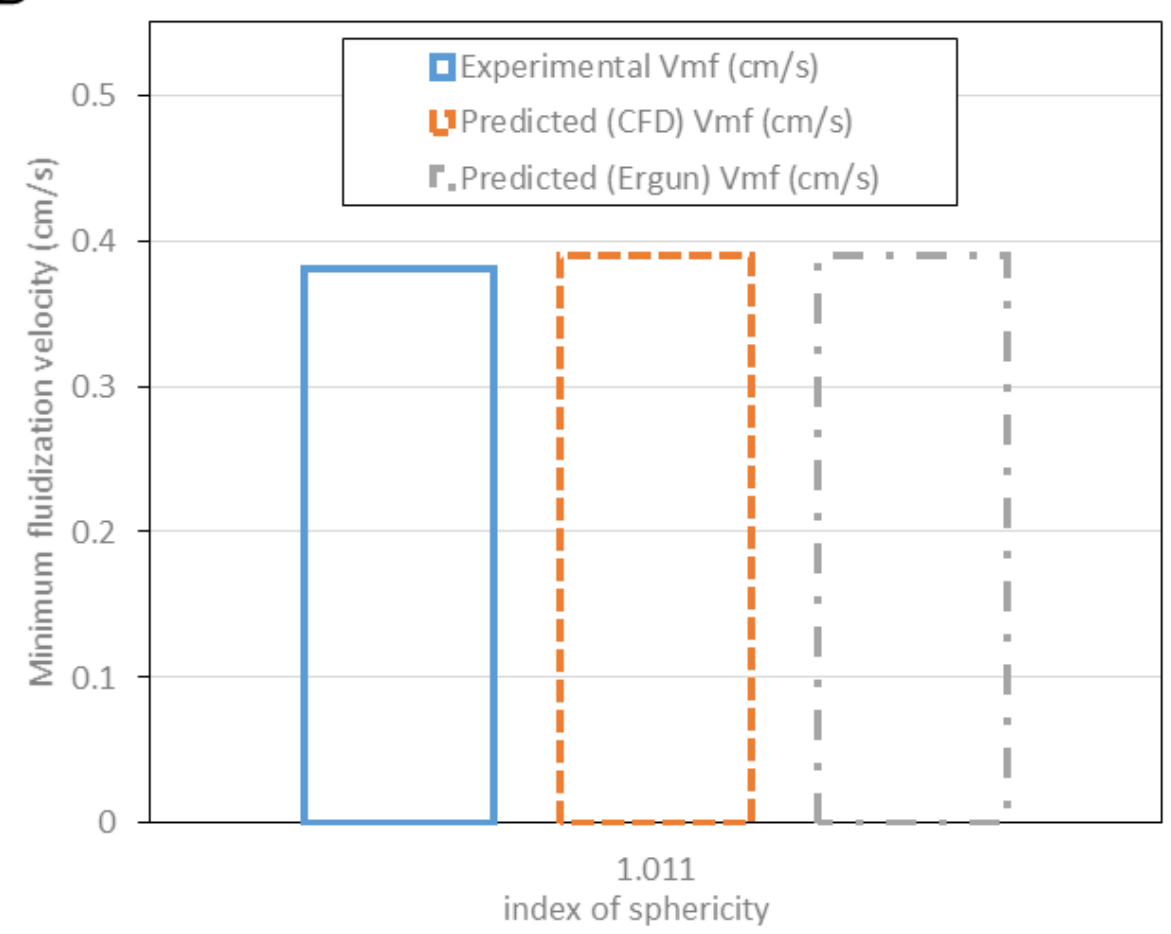

Figure 3: (A) Fluidization plot of calcium alginate bed height as a function of the superficial liquid velocity. (B) Measured and estimated (using Ergun and the Eulerian-Eulerian model) minimum fluidization velocities. The results shown are from calcium alginate carriers with an index of sphericity of 1.011. 


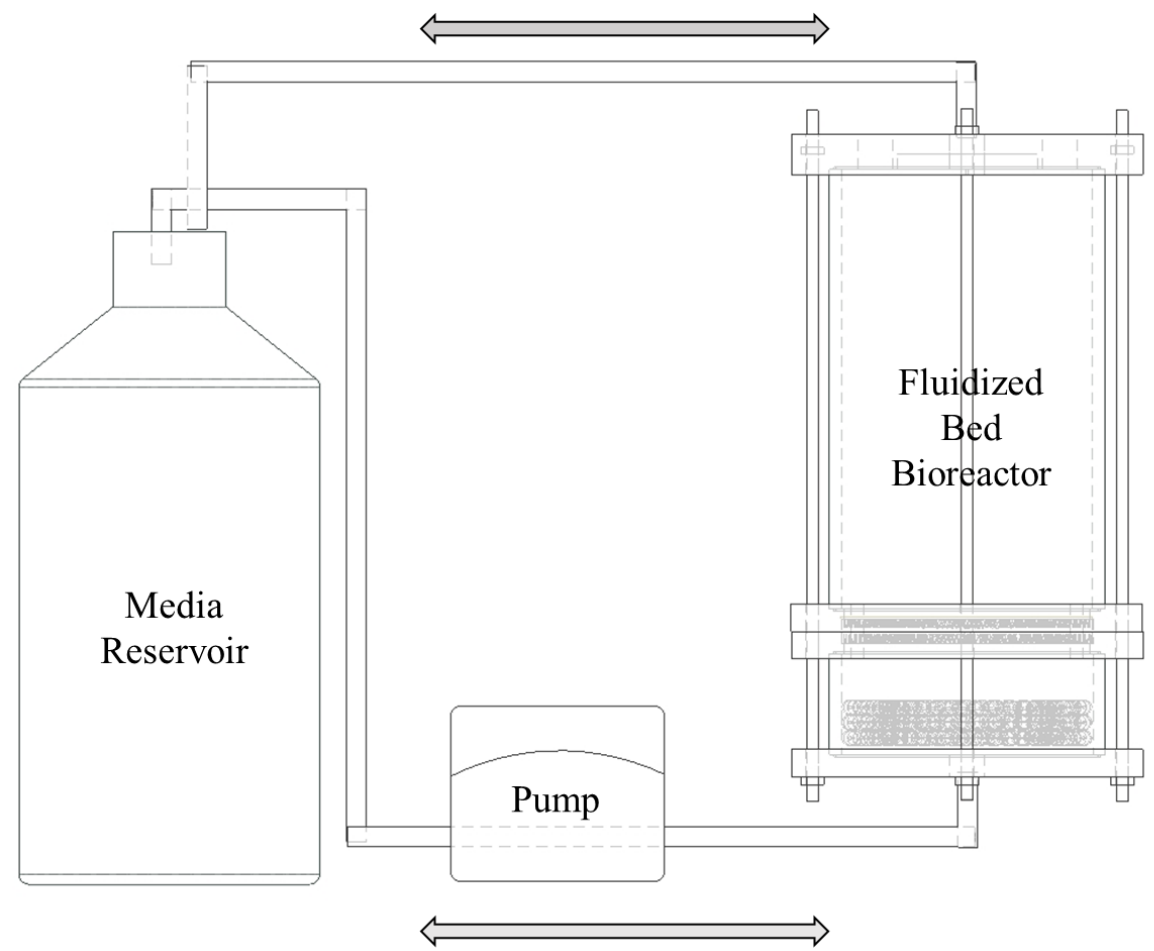

Figure 4: Schematic diagram of bioreactor set-up for biological validation, along with media reservior vessel and pump.

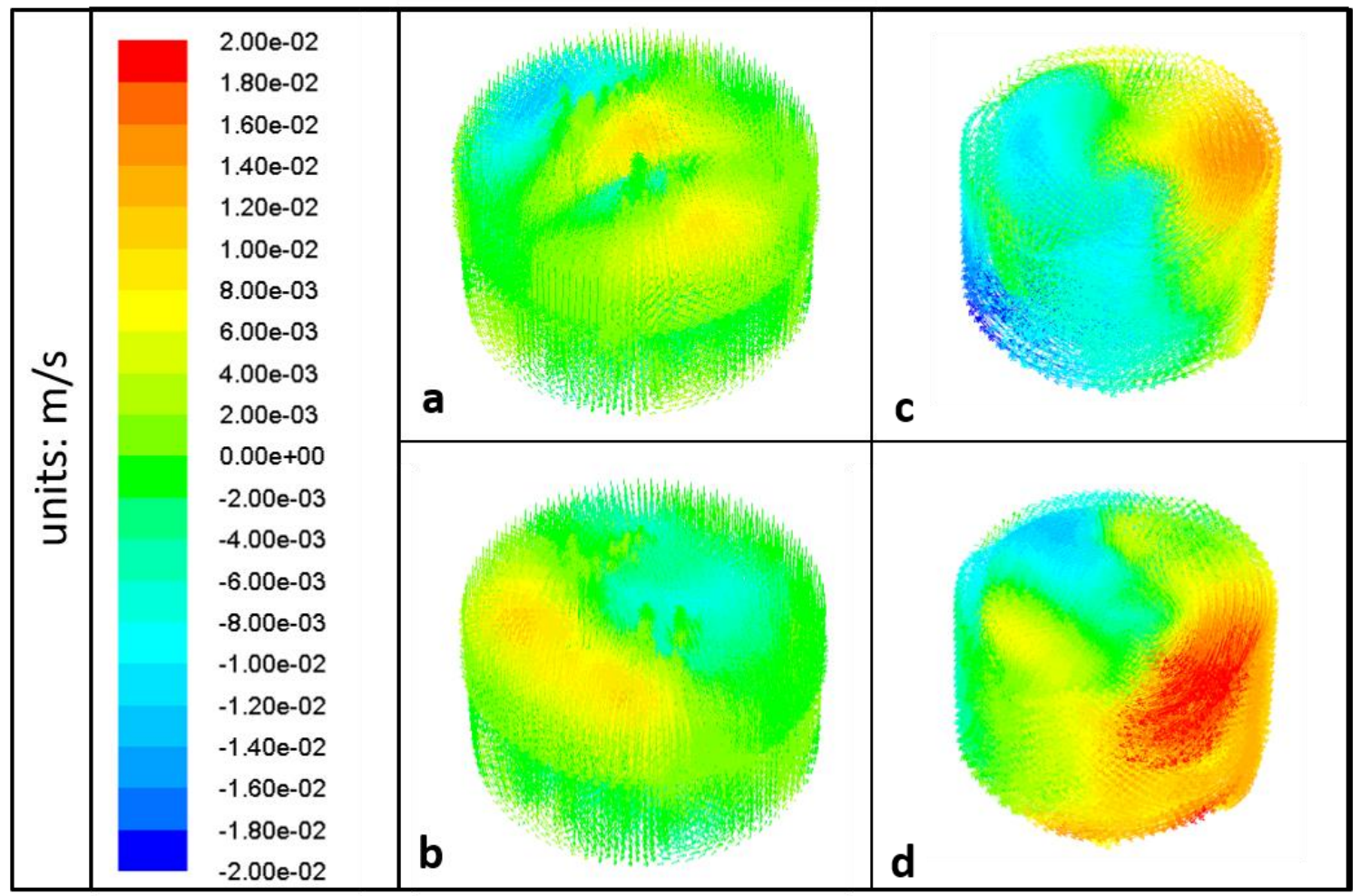

Figure 5: CFD generated vector plot obtained at a liquid superficial velocity of $0.002 \mathrm{~m} / \mathrm{s}$ with flow distributor channels at $0^{\circ}$ and $45^{\circ}$ relative to the vertical plane: Vectors in figures a) and c) represent the $\mathrm{x}$ direction, whilst $\mathrm{b}$ ) and $\mathrm{d}$ ) represent the $\mathrm{z}$ direction. Units are in $\mathrm{m} / \mathrm{s}$. 
A

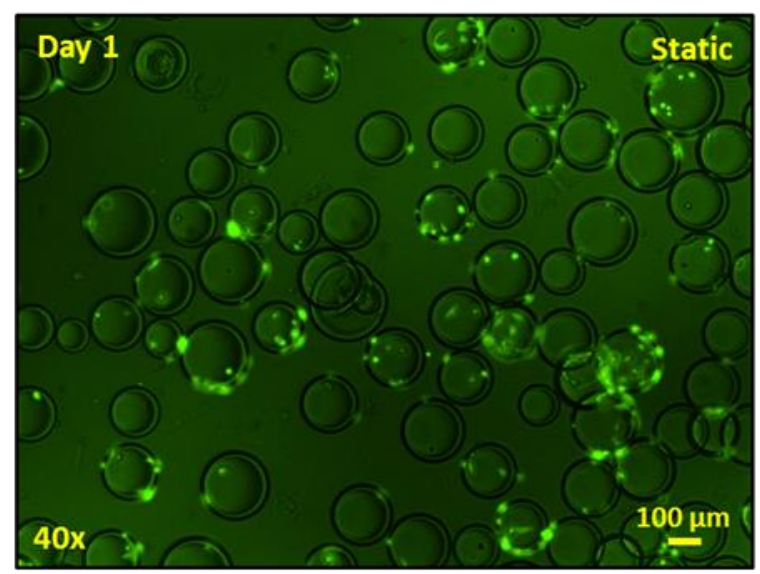

B

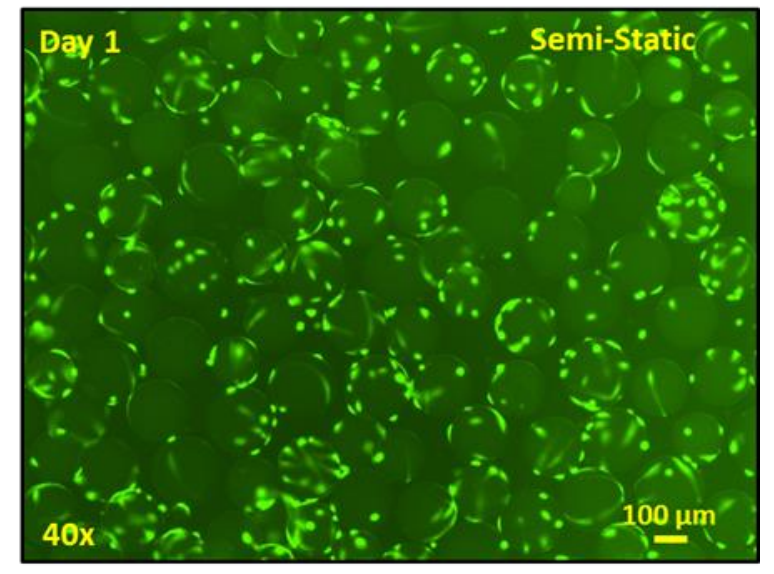

Figure 6: Image of green fluorescent hTERT MSCs 1 day after seeded onto Cytodex 1 microcarriers in (A) a static glass bottle and (B) fluidized bed bioreactor with $45^{\circ}$ angled flow channels.

A
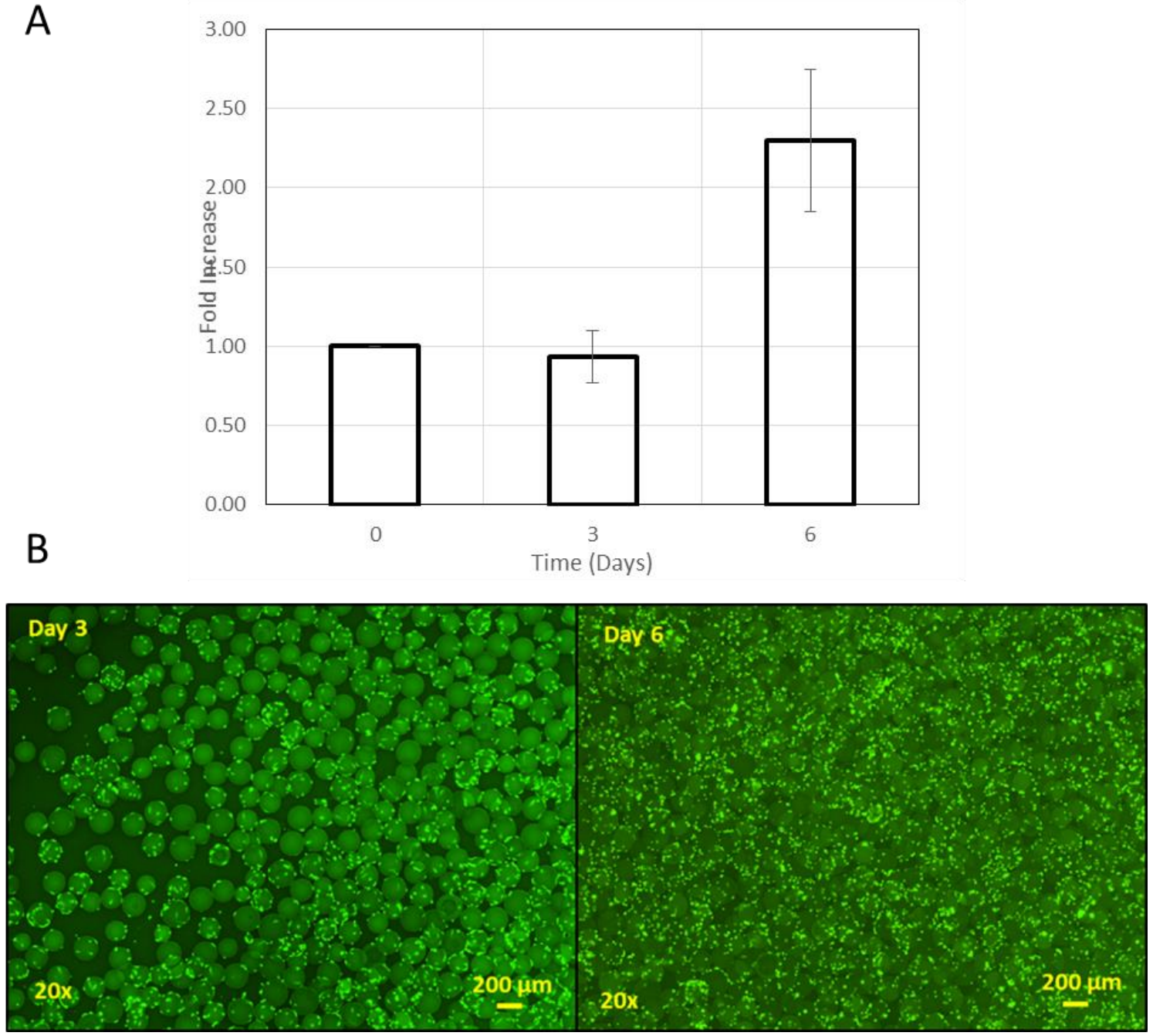

Figure 7: (A) hMSC fold expansion compared to day 0 as a function of time during. Fluidized Bed cell culture (error bars are standard error) and (B): Fluorescence microscopy images of hTERT MSCs 
attached to Cytodex 1 microcarriers in the bespoke fluidized bed bioreactor on day 3 and day 6 of the cell culture. 